TABLE 7

APSA National Salary Scale 1995-96

\begin{tabular}{|c|c|c|c|c|c|c|}
\hline \multirow[b]{2}{*}{ APSA Position } & \multirow{2}{*}{$\begin{array}{c}\text { Equivalent } \\
\text { Government } \\
\text { Grade } \\
\end{array}$} & \multirow{2}{*}{$\begin{array}{c}1995 \\
\text { Federal } \\
\text { Salary Scale } \\
\end{array}$} & \multirow{2}{*}{$\begin{array}{c}1995-96 \\
\text { APSA } \\
\text { Grade } \\
\end{array}$} & \multirow{2}{*}{$\begin{array}{c}\text { 1995-96 } \\
\text { APSA } \\
\text { Salary Scale } \\
\end{array}$} & \multicolumn{2}{|c|}{$\begin{array}{l}\text { Number of } \\
\text { Employees }\end{array}$} \\
\hline & & & & & FT & PT \\
\hline $\begin{array}{l}\text { Political Scientists: } \\
\text { Executive Director }\end{array}$ & SE & 5 & 8 & & & \\
\hline Deputy Director & 15 & $71,664-93,166$ & 7 & $65,000-91,000$ & 1 & \\
\hline Program Directors & $13-14$ & $51,557-79,200$ & 6 & $48,000-85,500$ & 2 & 1 \\
\hline Non-Political Scien & & & & & & \\
\hline Program Managers & $11-12$ & $36,174-56,362$ & 5 & $34,500-44,000$ & 4 & \\
\hline $\begin{array}{l}\text { Senior Administrative } \\
\text { Assistant }\end{array}$ & $9-10$ & $29,898-42,808$ & 4 & $28,500-40,500$ & 3 & \\
\hline $\begin{array}{l}\text { Administrative Assistant; } \\
\text { Building Manager }\end{array}$ & $7-8$ & $24,441-35,185$ & 3 & $22,000-34,000$ & 5 & \\
\hline Secretary, Receptionist & $4-6$ & $17,637-28,592$ & 2 & $19,000-28,500$ & 5 & \\
\hline
\end{tabular}

Elections Committee:

John Ferejohn, Stanford University

Helen Milner, Columbia University

Dianne Pinderhughes, University of Illinois at UrbanaChampaign

Rules Committee:

Rodney Hero, University of Colorado-Boulder

Susan MacManus, University of South Florida

Harvey Starr, University of South Carolina

\section{APSA Gopher Report}

\section{Matthew Linkie, APSA}

The increasing popularity and usefulness of the Internet has prompted APSA to locate material relevant to the political scientist. Through the efforts of several of it's members, APSA has selected gopher and web sites containing such information. APSA has made accessible its own gopher site with the help of Bill Ball, Department of Political Science, Trenton State University, and is currently working on developing a site on the World Wide Web.

A gopher provides you with the capability to move around the Internet by selecting categories of information. It is a link from your terminal to others around the world. The APSA gopher project is moderated and edited by Gary Klass, Department of Political Sci- ence, Illinois State University and Michael Margolis, Department of Political Science, University of Cincinnati.

Accessing the APSA gopher server enables you to discover files which APSA is making available and to connect to computers around the world holding political science research documents, press releases, and updates on worldwide political current events.

The APSA gopher server is designed to work in conjunction with the Political Science Research and Teaching List (PSRT-L) which itself has approximately 1400 subscribers in 44 countries. PSRT-L is a moderated discussion list (send the command "subscribe psrt-l, your name"' to listserv@mizzou1. missouri.edu to join).

This year, the APSA gopher currently averages 150 accesses a day. The root menu is as follows:

About the American Political Science Association Gopher

American Government Gopher at Northwestern University

Comparative Politics

International Relations

Political Theory

Public Policy and Public Administration

Computers, Software \& Data

APSA Information \& Services

Conference Information

Scholarships, Fellowships, \& Grants

Journal Information

The Political Science List of Lists
E-Mail Directory of Political Scientists

Related Gophers and Reference Information

The APSA Information \& Services menu includes documents on APSA's publications, fellowships and grants, awards, membership, and other services, all of which are updated regularly.

To access the APSA gopher server, select the "gopher client" option from your main menu. If you are unfamiliar with using gopher servers or do not have a "gopher client" option on your main menu, contact whoever provides your access to the Internet.

After selecting the "gopher client," type apsa.trenton.edu, and hit enter. The above menu will appear.

Connecting to other gopher servers is just as easy. The following list contains brief descriptions of gopher sites available on the Internet:

\section{gopher.csg.org}

Provides information about the Council of State Governments and state programs, plus links to state legislative gopher servers.

\section{gopher,igc.apc.org}

Select WomensNet. News, reports and background information from the Fourth World Conference on Women, September 1995, Beijing, China.

\section{gopher.nara.gov}

National Archives and Records Administration and the Office of the Federal Register.

\section{gopher.usia.gov}

Documents, reports and commentary from the United States Information Agency.

sailor.lib.md.us

Maryland Information Network provides general information on Maryland government, as well as federal, foreign, and other state governments.

To access these sites simply select the "gopher client" option from your main menu. Type in the name of the gopher site, and hit enter. This will connect you to that particular site's root menu. 
The World Wide Web (WWW) allows users to view text as well as graphics, video, and sound. Like the gopher, special software is needed to access web pages. The following sites contain information relevant to political science:

\section{http://now.org.now/home.html}

National Organization for Women provides information on economic equity, electoral politics, global feminism, and other women's rights issues.

\section{http://www.cnn.com}

Reports and archives of CNN. Updated daily.

http://www.law.vill.edu/

Villanova Center for Information Law and Policy provides an index to Federal Government and Federal Judiciary web sites.

\section{http://www.newslink.org}

Hundreds of on-line newspapers, broadcasters, magazines, and news services.

\section{http://www.vote-smart.org}

Includes links to '96 Presidential campaign and political issues and organizations, made available by Project Vote-Smart.

Suggestions or comments on other gopher links and web sites can be sent by e-mail to Matt Linkie at mlinkie@apsa.com.

\section{McClain and Rice Commended at the 1995 Annual Meeting}

Paula D. McClain, University of Virginia, and Mitchell F. Rice, Louisiana State University, were honored by the APSA Committee on the Status of Blacks in the Profession at the 1995 Annual Meeting in Chicago. Plaques were bestowed on these scholars at the annual nightcap reception on Friday, September 1, at the Chicago Hilton and Towers Hotel. The Committee began honoring political scientists in 1976 to commend those who have advanced the interest of black political scientists and have distinguished themselves as scholars and teachers.
Sheila D. Ards, University of Minnesota, is chair of the Committee on the Status of Blacks. Other members include Ally Faye Mack, Jackson State University; Charles E. Jones, Georgia State University; Hoda Zaki, Hood College; Kathie Golden, Morgan State University; and Walter Mebane, Cornell University.

Paula D. McClain is a member of the Department of Government and Foreign Affairs at the University of Virginia. She received her Ph.D. from Howard University in 1977. She has also taught at Arizona State University and the University of Wisconsin at Milwaukee.

McClain has written or edited five books, seven book chapters and over twenty-two refereed articles. In addition to serving as President of the National Conference of Black Political Scientists and as Vice-President and Program CoChair, APSA 1993 Annual Meeting, she has held a plethora of offices with the following professional associations: National Conference of Black Political Scientists, the American Political Science Association, the Western Political Science Association, the Midwest Political Science Association, the Southern Political Science Association, and Policy Studies Organization.

Mitchell F. Rice, Professor of Public Administration, Public Administration Institute and Professor

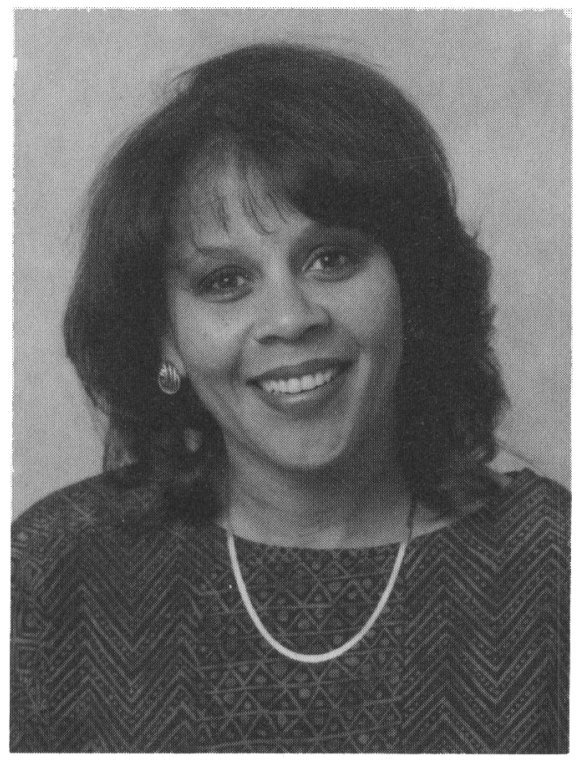

Paula D. McClain

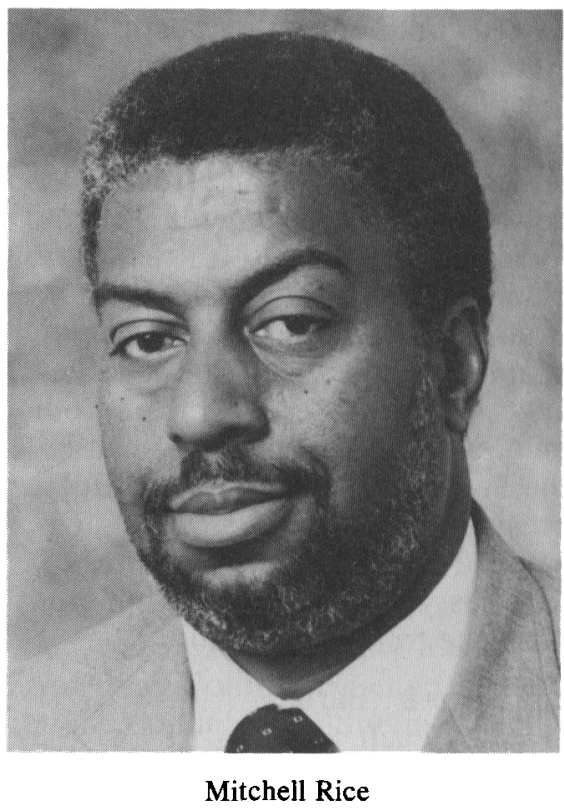

of Political Science, Louisiana State University, received his Ph.D. from Claremont University in 1976. He has taught at Southwest Texas State University and at Prairie View A\&M University.

Rice has written or edited six books, thirteen book chapters, and fifty-seven scholarly articles. He has also served as officers in the following professional associations: American Political Science Association, American Public Health Association, American Society for Public Administration, National Conference of Black Political Scientists, National Conference of Minority Public Administrations, National Forum of Black Public Administrations, the Southern Political Science Association, and the Southwestern Political Science Association.

\section{Schuck Campaign Continues}

The response to the 1994 campaign on behalf of the Victoria Schuck endowment which supports an award for the best book on women and politics was excellent: individual contributions came to $\$ 2,500$ and Vicki gave a gift of an additional $\$ 2,000$. As of 1995 , this endowment had sufficient funds to support an award every other year. But, $\$ 3,600$ more was needed to 